reserved through the Organising Committee. Intimation of attendance at the Congress should be sent as soon as possible to the Secretary of the Organising Committee, Mr. G. V. Jacks, Imperial Bureau of Soil Science, Harpenden, England, from whom all further information may be obtained.

\section{International Botanical Congress}

A PReliminary programme has been circulated of the Sixth International Botanical Congress, to be held in Amsterdam on September 2-7 of this year, under the presidency of Prof. F. A. F. C. Went. An executive committee of Dutch botanists, with Dr. M. J. Sirks of Wageningen as secretary, has divided the Congress into ten sections: agronomy, cytology, genetics, geobotany, morphology and anatomy, mycology and bacteriology, phytopathology, palæobotany, plant physiology, taxonomy and nomenclature. The presidents and vice-presidents of sections are already announced, as well as the topics chosen for discussion in each section, and some of the principal speakers. The subjects for discussion include many of the current problems in all phases of botany, and some will be considered jointly by two or more sections. A number of excursions to various parts of Holland are being arranged to follow the Congress.

\section{Announcements}

Tre second award, by the Wilhelm Roux Stiftung für Entwicklungsmechanik, of the medal founded in commemoration of Wilhelm Roux, who died on September 15, 1924, has recently been made to Dr. Jan Boeke, professor of histology in the University of Utrecht, for his researches on the development of the nervous system.

SIR LeONARD HILL writes : "In my letter on 'The 1933 Everest Climbing Expedition and Oxygen' [Nature, Dec. 22, p. 969], I say 'animals cannot live for more than six weeks' in oxygen equal to 10 per cent of one atmosphere. The words 'without serious deterioration' should have been added."

The Royal Photographic Society, 35 Russell Square, W.C.1, is now holding its sixth exhibition in the series, "Photography in the Service of Mankind". The present exhibition is devoted to exploration and travel, and includes records from most of the great expeditions which have taken place during the last fifteen years. The Exhibition will remain open to the public on week-days from 10 a.m. to 6 p.m. until January 31.

THE Iron and Steel Institute, in co-operation with other societies and technical institutions, will hold a symposium on the "Welding of Iron and Steel" on May 2-3. The symposium, which will be held in connexion with the annual meeting of the Institute, will take place in the lecture theatre of the Institution of Civil Engineers, Great George Street, Westminster, London, S.W.1. Further information can be obtained from the Secretary, Iron and Steel Institute, 28 Victoria Street, London, S.W.1.
THE annual general meeting of the Institute of Metals will be held in London on March 6-7. On March 5, there will be an additional session with other technical institutions when a discussion will take place on "Problems of Cold Presswork", to be opened by Dr. H. J. Gough. The discussion will be held at the house of the Royal Geographical Society. The annual May Lecture of the Institute will be delivered by Prof. W. L. Bragg, whose subject will be "The Atomic Arrangement of Metals and Alloys". The annual autumn meeting of the Institute will be held in Newcastle-on-Tyne. Further information can be obtained from the Secretary, 36 Victoria Street, London, S.W.I.

The French Society for the Propagation of Cremation, founded in 1880, has nominated as its president Prof. G. Barrier, formerly president of the Academy of Medicine, in succession to the late Prof. Léon Bernard, and Dr. G. Ichok as general secretary. The offices of the Society have been transferred to 10 rue Fanny, Clichy, Seine.

A course of six public lectures on different aspects of "Time" will be given at Bedford College, commencing on January 17. The lecturers will be Prof. F. C. Bartlett (January 17), Dr. J. K. Fotheringham (January 31), Lieut.-Comm. R. T. Gould (February 14), Dr. R. A. Sampson (February 28), Sir Arthur Eddington (March 7), and Prof. C. D. Broad (March 14). Cards of admission can be obtained from the Secretary, Bedford College, Regent's Park, N.W.1.

Prof. F. E. Fritsch, of Queen Mary College, London, has completed the first volume of the first comprehensive account in the English language of the morphology of the Algæ. It is entitled "The Structure and Reproduction of the Algæ", and is designed for use by university students as well as by research workers. The book will be published this month by the Cambridge University Press.

A COMPREHENSIVE catalogue of zoological material for use in schools and colleges has been issued by Messrs. E. Gerrard and Sons, 61 College Place, London, N.W.1. The 64 pages contain very complete lists of stock species, from Protozoa to mammals, for examination or dissection, of mounted specimens, injected and dissected, cartilaginous skeletons, and life-histories. Prices are moderate, and our experience of the preparations, all of which are made by Messrs. Gerrard, is that they are of reliable quality.

Applications are invited for the following appointments, on or before the dates mentioned :-A lecturer in agriculture and warden at the Kent Farm Institute -The Principal, Kent Farm Institute, Borden, Sittingbourne (Jan. 21). A full-time physicist in the London County Council's Hospital Service-The Clerk of the Council, County Hall, Westminster Bridge, S.E.1 (Jan. 25). A keeper of the Department of Geology in the public museums of Liverpool-The Town Clerk, Municipal Buildings, Dale Street, Liverpool, 2 (Feb. 5). A University professor of physiology at St. Mary's Hospital Medical School-The Academic Registrar, University of London, S.W.7 (Feb. 15). 